\title{
COVID-19 and Mental Health
}

\author{
COVID-19 ve Ruh Sağlığı
}

\author{
Mustafa ARI ${ }^{1}$ \\ (i) 0000-0002-8003-1661 \\ Taşkın DUMAN ${ }^{2}$ \\ (D) 0000-0002-6552-4193
}

\begin{abstract}
Because of their epidemic nature, infections such as coronavirus disease 2019 (COVID-19) pandemic cause neuropsychological and social problems which are significantly different from other known infections. Many studies on the COVID-19 pandemic have shown higher levels of mental problems such as anxiety, depression, panic disorder, and obsessive compulsive disorder especially in patients and individuals who are in the risk group. Due to biopsychosocial characteristics of people, infections, especially epidemic infections, seriously impair the quality of life by dramatically affecting these three structures, namely biology, psychology and social quality of life of a person. As numerous studies have shown, the entire human innate and adaptive immune system and the psychological and mental state of an individual are directly linked. Many studies have reported that quarantine and social restrictions can trigger depressive symptoms such as anxiety, obsession, and anhedonia. Some researchers have claimed that information from unknown sources on social media increases the psychological and psychosocial symptoms of obsession, anxiety and fear of death. Consequently, a multidisciplinary study is necessary in the treatment and prevention of
\end{abstract} ${ }^{1}$ Mustafa Kemal University Faculty of coronavirus pandemic.

Medicine Department of Psychiatry, Keywords: Coronavirus; anxiety; depression; stress.

Hatay, Turkey

${ }^{2}$ Mustafa Kemal University Faculty of Medicine Department of Neurology, Hatay, Turkey

\section{Corresponding Author Sorumlu Yazar \\ Mustafa ARI \\ drkaan1976@gmail.com}

Received / Geliş Tarihi : 04.09.2020 Accepted / Kabul Tarihi : 22.10.2020 Available Online /

Çevrimiçi Yayın Tarihi : 25.11.2020

\section{ÖZ}

Salgın doğaları nedeniyle; koronavirüs hastalığı 2019 (coronavirus disease 2019, COVID-19) pandemisi gibi enfeksiyonlar, bilinen diğer enfeksiyonlardan önemli ölçüde farklı olan nöropsikolojik ve sosyal sorunlara neden olur. COVID-19 pandemisi ile ilgili birçok çalışma, özellikle hastalarda ve risk grubunda yer alan bireylerde anksiyete, depresyon, panik bozukluğu ve obsesif kompulsif bozukluk gibi zihinsel problemlerin daha yüksek seviyelerde olduğunu göstermiştir. İnsanın biyopsikososyal özelliklere sahip olmasından dolayı; enfeksiyonlar, özellikle salgın enfeksiyonlar, kişinin biyoloji, psikoloji ve sosyal yaşam kalitesi olmak üzere, bu üç yapıyı da sarsıcı derecede etkileyerek yaşam kalitesini ciddi şekilde düşürmektedir. Çok sayıda çalışmanın gösterdiği gibi, insan doğal ve adaptif bağışıklık sisteminin bütünü ve bir bireyin psikolojik ve zihinsel durumu doğrudan bağlantı içindedir. Karantina ve sosyal kısıtlamaların anksiyete, takıntı ve anhedoni gibi depresif belirtileri tetikleyebileceği birçok çalışmada bildirilmiştir. Bazı araştırmacılar, sosyal medyadan elde edilen kaynağı belirsiz bilgilerin obsesyon, kaygı ve ölüm korkusunun psikolojik ve psikososyal belirtilerini artırdığını iddia etmişlerdir. Sonuç olarak, koronavirüs pandemisinin tedavisinde ve önlenmesinde multidisipliner çalışma gereklidir.

Anahtar kelimeler: Coronavirüs; anksiyete; depresyon; stres. 


\section{INTRODUCTION}

It has been determined that psychological stress factors affect the immune system for many years. Changes in the immune system have also been found to affect the individual's psychology. Cytokines cause changes in monoamine metabolism, especially serotonin. Cytokines such as IL-1, IL-6, TNF- $\alpha$ lead to upregulation in serotonin transporter (SERT) mRNA and proteins. Thus, the neurotransmission of serotonin increases and the amount of serotonin decreases (1). Serotonin is synthesized from tryptophan. It is claimed that serotonin/SERT and inflammation interaction may be a common and important point in the development of depression, obsessions and anxiety. These cytokines form kinetic and linolenic acids, which are neurotoxic tryptophan metabolites thanks to the changes in the metabolism of tryptophan. 5-OH tryptophan and amino acid decarboxylase are key enzymes in the synthesis of serotonin. Tryptophan is converted to quinurine and quinolinic acid by the enzyme 2,3-dioxygenase (IDO). Cytokines (TNF- $\alpha$, IL-1 $\beta$, IL-6, INF-gamma) induce central and peripheral IDO enzyme activity. As a result, the formation of quinolinic acid, which has neurotoxic properties, increases and the conversion of tryptophan to serotonin decreases. These metabolites also cause glutamate neurotoxicity. The increase in the release of glutamate will also cause disruption of the brain's compatibility as the release of neuroprotective and neuroplastic agents such as brain-derived neurotrophic factor (BDNF) decreases $(1,2)$.

\section{COVID-19 AND STRESS}

The stress-HPA axis relationship has been known for a long time. Stress stimulates the release of corticotropin releasing hormone $(\mathrm{CRH})$ and adrenocorticotropic hormone (ACTH), and this also stimulates the release of glucocorticoids from the adrenal glands. The control is provided by negative feedback. Proinflammatory cytokines disrupt negative feedback by causing desensitization at glucocorticoid receptors. Thus, HPA axis activity is constantly stimulated. Response to acute stress occurs with the activation of HPA axis, but long-term problems arise when the stress becomes chronic (3). In the studies, high stress burden resulted in post-traumatic stress disorder in the SARS process (4) and depressive disorders appeared as the most common long-term psychological problem (5).

\section{EFFECTS OF SOCIAL ISOLATION ON MENTAL HEALTH IN COVID-19}

The coronavirus disease 2019 (COVID-19) pandemic negatively affects human health, resulting in death, quarantine practices and restrictions on commute which lead to depression and stress (6). It also remarkably triggers the psychological crisis and increases the risks of permanent psychological distress (7). The uncertain and persistent threat in the COVID-19 outbreak can cause fear to become chronic and severe (8).

Due to this epidemic disease, denial, shock and surprise responses, which are typical trauma responses, are expected in individuals. Denial is a mental defense response that all people initially use as a coping tool, and reflects the difficulty in accepting the disease (9).

Tian et al. (10), in their research in China during the epidemic, have found that people under the age of 18 and over 50, individuals with a lower education level than higher education, individuals who are divorced or widowed, agricultural workers and those who are in the minority position have more obsessive compulsive symptoms, interpersonal sensitivity, phobic anxiety and psychotic symptoms. In general, older individuals who are more concerned about becoming infected and dying develop more serious and psychological symptoms that need to be focused on (11).

\section{COVID-19 AND ANXIETY}

Studies conducted in China during the COVID-19 outbreak reported that the level of anxiety of healthcare workers was very high. Compared to the normal population, it has been reported that they show significantly worse symptoms of depression, anxiety, and post-traumatic stress (12). The increase in the level of anxiety was found to be related to the high risk of infection of these individuals, whether their institution is providing adequate psychological support program, the lack of knowledge of the person's emergency response plans and high workload (13).

Cao et al. (14) stated that living in urban areas instead of rural areas, living with the family and having fixed and regular income were urban protective factors during the COVID-19 pandemic. In the same study, it was found that having family members, relatives or acquaintances infected with the COVID-19 virus increased anxiety.

The emptying of supermarket shelves in the first days of the outbreak, staying at home, interpretation of every bodily sensation as a sign of COVID-19, exposure of minds to misinformation due to social media posts, watching outbreak programs on the internet and television for long hours increased fear and panic. In a study in Mexico, after the influenza epidemic was widely covered in the media, it was found that individuals' risk perception and threat of uncertainty increased to a high level and their quality of life decreased (15).

In addition to all these factors, psychological resilience, which is defined as the ability to easily get rid of trouble and use positive emotions in negative conditions, is considered to be an important factor for COVID-19. Moreover, psychological resilience can be a protective factor against the development of psychopathology in individuals facing difficulties (16). Psychological resilience (6), which is generally associated with stress, is the most important factor in the process of adaptation to traumatic experiences such as epidemics, and it is a concept that requires individuals' efforts, time and continuity to deal with stress (17). In the research, a significant difference was found between post-epidemic thoughts and psychological resilience.

When the thoughts after the epidemic were examined, no significant difference was found between the thoughts stated as "my thoughts have not changed after the epidemic", "what do I do if myself, my child or my parents are infected", "we cannot get rid of the epidemic, the end of the world is coming" and "I don't want to die apart from my loved ones under quarantine". According to these results, it can be said that focusing on the thoughts after the epidemic reduces psychological resilience. Continuous focus on negative thoughts has negative effects on individuals' psychological health (18). 


\section{RISK GROUPS IN COVID-19}

Some researchers suggest that people who will be exposed to more negative results in COVID-19 outbreak are the elderly, the youth, the women, the students, the immigrants (19), the prisoners and the homeless $(18,20)$. The most painful and destructive effect of stigma is that people think that they are no longer a member of the society in which they used to feel connected to. Due to the exclusionary attitude of the society, the individuals feel increasingly lonely and withdraw from their environment. Thoughts such as social withdrawal, pessimism, hopelessness, inadequacy, helplessness, and guilt may trigger mental illnesses. After a while, most of those who experience stigma adopt these prejudiced, stereotyped thoughts themselves. In addition to those, some issues may start to arise and affect people's daily life after their being exposed to the feelings of pessimism, hopelessness, weakness, guilt and embarrassment, anxieties and fears about the future, intense anger and a desire to harm themselves or those around them as they think they deserve it. People may deny or hide the disease to avoid discrimination. Stigmatization may increase the anxiety of a person by preventing access to sufficient and accurate information about the disease. People may not want to access health services immediately and may apply in the late period. They may refuse treatment or may not comply with the treatment protocol due to the feeling of hopelessness. Those in the stigmatizing group, on the other hand, may neglect to take necessary protective measures, mistaking that they are protected against this disease, which is dangerous and contagious for everyone. In another study, it was found that potentially high-risk individuals, people who were suspected of infection, and individuals who were in close contact with the infected people during the COVID-19 outbreak experienced negative psychological effects even if they did not develop the infection and remained physically well (22).

After the social isolation and quarantine processes that came with the COVID-19 outbreak, individuals started to spend more time at home with their families. Although social isolation is an effective policy for controlling infection, it increases domestic violence and alcohol use so that it brings serious social, psychological, economic and social consequences $(23,24)$.

\section{CONCLUSION}

Under the light of all these findings, it seems rational to consider the pandemic as a psychological crisis and to accept that the uncertainty and unpredictability inherent in this crisis will have social, psychological and behavioral effects. Therefore, it is important to consider the negative effects of domestic violence as well as the individual consequences of the epidemic, and take steps to protect women, children and the elderly at risk. In conclusion, it is important to consider psychosocial factors in the treatment and prevention studies of COVID-19. Multidisciplinary work is essential for success when dealing with a pandemic, and taking necessary measures accordingly before, during and after is crucial.

Conflict of Interest: None declared by the authors.

Financial Disclosure: None declared by the authors.

Acknowledgements: None declared by the authors.

\section{REFERENCES}

1. Jones KA, Thomsen C. The role of the innate immune system in psychiatric disorders. Mol Cell Neurosci. 2013;53:52-62.

2. Duivis HE, Vogelzangs N, Kupper N, de Jonge P, Penninx BWJH. Differential association of somatic and cognitive symptoms of depression and anxiety with inflammation: findings from the Netherlands Study of Depression and Anxiety (NESDA). Psychoneuroendocrinology. 2013;38(9):1573-85.

3. Sözeri-Varma G. Neuroinflammatory hypothesis in major depressive disorder. Current Approaches in Psychiatry. 2014;6(1):1-9.

4. Cai H, Tu B, Ma J, Chen L, Fu L, Jiang Y, et al. Psychological impact and coping strategies of frontline medical staff in Hunan between January and March 2020 during the outbreak of coronavirus disease 2019 (COVID-19) in Hubei, China. Med Sci Monit, 26:e924171.

5. Huang Y, Zhao N. Generalized anxiety disorder, depressive symptoms and sleep quality during COVID -19 outbreak in China: a web web-based crosssectional survey. Psychiatry Res. 2020;288:112954.

6. Fardin MA. COVID-19 and anxiety: A review of psychological impacts of infectious disease outbreaks. Arch Clin Infect Dis. 2020;15(COVID-19):e102779.

7. Liu D, Ren Y, Yan F, Li Y, Xu X, Yu X, et al. Psychological impact and predisposing factors of the coronavirus disease 2019 (COVID-19) pandemic on general public in China. SSRN Electronic Journal. 2020. doi: 10.2139/ssrn.3551415.

8. Mertens G, Gerritsen L, Duijndam S, Salemink E, Engelhard IM. Fear of the coronavirus (COVID-19): Predictors in an online study conducted in March 2020. J Anxiety Disord. 2020;74:102258.

9. Janoff-Bulman R, Timko C. Coping with traumatic life events. In: Snyder CR, Ford CE, editors. Coping with negative life events. Boston, MA: Springer; 1987. p.135-59.

10. van Hoek AJ, Underwood A, Jit M, Miller E, Edmunds WJ. The impact of pandemic influenza H1N1 on health-related quality of life: a prospective populationbased study. PloS One. 2011;6(3):e17030.

11. Chen Q, Liang M, Li Y, Guo J, Fei D, Wang L, et al. Mental health care for medical staff in China during the COVID-19 outbreak. Lancet Psychiatry. 2020;7(4):e15-6.

12. Lee AM, Wong JG, McAlonan GM, Cheung V, Cheung C, Sham PC, et al. Stress and psychological distress among SARS survivors 1 year after the outbreak. Can J Psychiatry. 2007;52(4):233-40.

13. Pan R, Zhang L, Pan J. The anxiety status of Chinese medical workers during the epidemic of COVID-19: A meta-analysis. Psychiatry Investig. 2020;17(5):475-80.

14. Cao W, Fang Z, Hou G, Han M, Xu X, Dong J, Zheng J. The psychological impact of the COVID-19 epidemic on college students in China. Psychiatry Res. 2020;287:112934.

15. Jones JH, Salathé M. Early assessment of anxiety and behavioral response to novel swine-origin influenza A(H1N1). PLoS One. 2009;4(12):e8032.

16. Naeem F, Irfan M, Javed A. (2020). Coping with COVID-19: urgent need for building resilience through 
cognitive behaviour therapy. Khyber Med Univ J. 2020;12(1):1-3.

17. Koç Yıldırım P, Yıldırım E, Otrar M, Şirin A. Investigating relationship between psychological resilience and self-construal in adolescents. Marmara University Atatürk Education Faculty Journal of Educational Sciences. 2015;42(42):277-97.

18. Wang C, Pan R, Wan X, Tan Y, Xu L, Ho CS, et al. Immediate psychological responses and associated factors during the initial stage of the 2019 coronavirus disease (COVID-19) epidemic among the general population in China. Int $\mathbf{J}$ Environ Res Public Health. 2020;17(5):1729.

19. Tian F, Li H, Tian S, Yang J, Shao J, Tian C. Psychological symptoms of ordinary Chinese citizens based on SCL-90 during the level I emergency response to COVID-19. Psychiatry Res. 2020;288:112992.

20. Holmes EA, O'Connor RC, Perry VH, Tracey I,
Wessely S, Arseneault L, et al. Multidisciplinary research priorities for the COVID-19 pandemic: a call for action for mental health science. Lancet Psychiatry. 2020;7(6):547-60.

21. Bagcchi S. Stigma during the COVID-19 pandemic. Lancet Infect Dis. 2020;20(7):782.

22. Xiao H, Zhang Y, Kong D, Li S, Yang N. Social capital and sleep quality in individuals who self-isolated for 14 days during the coronavirus disease 2019 (COVID-19) outbreak in January 2020 in China. Med Sci Monit. 2020;26:e923921.

23. Ergönen AT, Biçen E, Ersoy G. Domestic violence during the COVID-19 pandemic. The Bulletin of Legal Medicine. 2020;25(Special Issue):48-57.

24. Usher K, Bhullar N, Durkin J, Gyamfi N, Jackson D. Family violence and COVID-19: Increased vulnerability and reduced options for support. Int $\mathbf{J}$ Ment Health Nurs. 2020;29(4):549-52. 